\title{
INDUÇÃO DA EXPRESSÃO DA MOLÉCULA INDOLEAMINA 2,3-DIOXIGENASE (IDO) COMO TERAPIA GÊNICA EM TRANSPLANTE DE ILHOTAS PANCREÁTICAS
}

\author{
Indoleamine 2,3-dioxygenase (IDO) expression induction as gene therapy in experimental pancreatic \\ islet transplantation
}

Humberto Dellê, Irene Lourdes Noronha

\begin{abstract}
RESUMO
O bloqueio da rejeição ao enxerto é fundamental para o sucesso do transplante de ilhotas pancreáticas (IP). Uma atraente alternativa surge do paradoxo imunológico durante a gravidez, onde a mãe não rejeita o feto imunologicamente distinto. Esta proteção pode ser devido à produção placentária de IDO. Objetivo: Construir um vetor para induzir a expressão de IDO em IP e analisar se a produção de IDO protege as IP em transplante alogênico experimental. Métodos: O cDNA da IDO foi isolado de placenta de ratas, ligado no vetor pcDNA 3,1 e transfectado em IP através de lipofecção. A expressão da IDO nas IP foi confirmada por RT-PCR, imuno-histoquímica e análise funcional. Ratos Lewis diabéticos induzidos por estreptozotocina (glicemia $>300 \mathrm{mg} / \mathrm{dL}$ ) receberam IP sob a cápsula renal e foram divididos em 3 grupos: ISO Tx (isogênico), ratos transplantados com IP de ratos Lewis; ALO Tx (alogênico), transplante com IP de ratos Sprague-Dawley (SD); e ALO+IDO Tx, transplante com IP de ratos SD transfectadas com vetor-IDO. Resultados: O grupo ISO permaneceu normoglicêmico pós-transplante, enquanto que o grupo ALO Tx voltou a apresentar hiperglicemia ( $>300 \mathrm{mg} / \mathrm{dL})$ logo após o transplante (11+1 dias). O grupo ALO+IDO Tx manteve-se com glicemia $<300 \mathrm{mg} / \mathrm{dL}$. No PO-45, o grupo ISO Tx apresentou níveis normais de insulina sérica $(0,55+0,13$ $\mathrm{ng} / \mathrm{mL})$, enquanto que o ALO Tx apresentou diminuição significativa $(0,14+0,02 \mathrm{ng} / \mathrm{mL} ; \mathrm{p}<0,05)$. O grupo ALO+IDO Tx apresentou níveis de insulina sérica significativamente maiores comparado ao ALO Tx $(0,33+0,04 \mathrm{ng} / \mathrm{mL} ; \mathrm{p}<0,05)$. Conclusão: A indução da expressão de IDO em IP confere proteção às IP, aumenta a sobrevida e promove um melhor controle metabólico.
\end{abstract}

Descritores: Ilhotas pancreáticas; Rejeição de enxerto; Terapia de Genes; Diabetes Melito

\section{Instituições:}

Laboratório de Nefrologia Celular, Genética e Molecular, Faculdade de Medicina da Universidade de São Paulo, São Paulo, Brasil

Correspondência:

Irene de Lourdes Noronha

Laboratório de Nefrologia Celular, Genética e Molecular

Faculdade de Medicina da Universidade de São Paulo

Av. Dr. Arnaldo, 455, sala 4304 - CEP: 01246-000 - São Paulo, Brasil

Fone: (11) 3061-8403

Fax: (11) 3061-8361

E-mail: irenenor@usp.br

Recebido em: 02.06.2009

Aceito em: 29.11.2009

\section{INTRODUÇÃO}

O transplante de ilhotas pancreáticas (IP) representa uma atraente alternativa de tratamento para o paciente diabético tipo 1. Essa modalidade de transplante celular pode restabelecer o controle metabólico do paciente diabético, estacionando ou até mesmo revertendo complicações secundárias tais como nefropatia, neuropatia e retinopatia diabética.1-3

O desenvolvimento da metodologia do transplante celular tem despertado grande interesse na comunidade científica, especialmente por se tratar de um procedimento simples, com poucas complicações e diminuição do tempo de hospitalização.4,5 No entanto, assim como em transplante de órgãos sólidos, o uso de drogas imunossupressoras de forma contínua é fundamental para o sucesso do transplante, com o inerente risco de seus efeitos colaterais.

Estratégias para evitar a rejeição sem comprometer o sistema imunológico do paciente têm sido intensamente investigadas, particularmente em transplante celular, onde as células podem ser manipuladas "in vitro" antes do transplante.

Neste contexto, o paradoxo imunológico observado na reprodução de mamíferos, onde antígenos fetais são tolerados pelo 
organismo materno, traz novos conceitos para a compreensão da imunomodulação. Durante a gravidez, o feto, que é considerado imunologicamente alogênico (por possuir metade dos genes paternos), não é rejeitado pela mãe. $\mathrm{O}$ intrigante mecanismo pelo qual o sistema imune da mãe reconhece o feto como self ainda não foi elucidado, porém, existem fortes evidências que a molécula indoleamina 2,3 dioxigenase (IDO), produzida pela placenta, possa exercer um importante papel. De fato, estudos realizados por Munn e colaboradores demonstraram que a inibição química de IDO durante a gravidez induziu aborto em camundongos, caracterizado por rejeição do tecido embrionário mediada por linfócitos T alorreativos. 6

O mecanismo pelo qual a IDO exerce efeito imunomodulador ainda não foi completamente elucidado, porém, a depleção de triptofano pode ser uma explicação, devido ao fato desse aminoácido ser essencial para a síntese de proteínas, e, portanto, para a proliferação celular.7 Assim, a depleção de triptofano impede a proliferação de linfócitos T alorreativos. Por outro lado, estudos mais recentes têm demonstrado que o efeito imunomodulador da IDO não se limita apenas à depleção de triptofano, mas também aos metabólitos que são gerados a partir daquele aminoácido, mais especificamente os derivados da quinurenina. Terness e colaboradores demonstraram que células dendríticas expressando IDO inibem a proliferação de linfócitos T "in vitro" e a adição de derivados da quinurenina potencializa esse efeito inibitório.8. Além de inibir a proliferação, os derivados da quinurenina induzem a apoptose em linfócitos $\mathrm{T}$ "in vitro" e suprimem timócitos alorreativos "in vivo". 9

Além disso, a indução da expressão de IDO em fibroblastos aumenta a sobrevida dessas células em xenotransplante.10 Estudos recentes demonstram que a IDO tem efeito imunomodulador e pode proteger o tecido transplantado,11-13 indicando sua possível utilização no transplante de IP. Estudo com camundongos espontaneamente diabéticos demonstrou que a indução da expressão de IDO previamente ao início da doença aumentou a sobrevida das IP nessa doença auto-imune.14 Baseado nesse novo conceito de proteção contra a resposta imune, o presente estudo teve como objetivo isolar o cDNA da IDO e transfectar esse cDNA em IP para induzir a expressão "in vivo" de IDO e, dessa forma, analisar seu efeito em modelo experimental de transplante alogênico de IP.

\section{MATERIAIS E MÉTODOS}

\section{Animais}

Para o presente estudo foram utilizadas três ratas grávidas da linhagem Lewis para isolamento do cDNA da IDO e 130 ratos machos das linhagens Lewis e Sprague-Dawley para realização do isolamento e do transplante de IP. Os ratos da linhagem Lewis foram criados no biotério local do Laboratório de Investigação Médica 16 (Faculdade de Medicina da USP) a partir de matrizes adquiridas comercialmente do Centro Multidisciplinar para Investigação Biológica (CEMIB) da UNICAMP. Já os animais da linhagem Sprague-Dawley foram obtidos do biotério do Instituto de Química da Universidade de São Paulo.

Toda metodologia aplicada no presente estudo foi aprovada pela Comissão de Ética para Análise de Projetos de Pesquisa do Hospital das Clínicas (CAPPESQ, protocolo 236/05) e pela Comissão Interna de Biossegurança do Departamento de Radiologia da Faculdade de Medicina da Universidade de São Paulo.

\section{Obtenção de IP para transplante experimental Isolamento de IP}

Para o isolamento de IP foram utilizados ratos machos Lewis ou Sprague-Dawley. Os animais foram anestesiados com ketamina/ xilazina e os pâncreas foram perfundidos com Liberase RI (Roche Laboratories, Indiana, EUA) e permaneceram a $37^{\circ} \mathrm{C}$ por 20 minutos para completa digestão. As IP foram purificadas através de gradiente contínuo de iodixanol, formado por quatro soluções de iodixanol (Visipaque, Roche Laboratories, Indiana, EUA) com diferentes densidades: 1,125 g/cm3, $1,110 \mathrm{~g} / \mathrm{cm} 3,1,080 \mathrm{~g} / \mathrm{cm} 3$ e $1,030 \mathrm{~g} / \mathrm{cm} 3$. O pellet formado por tecido pancreático foi resuspendido em $10 \mathrm{~mL}$ de iodixanol $1,125 \mathrm{~g} / \mathrm{cm} 3$. Em seguida, 10 $\mathrm{mL}$ de iodixanol $1,110 \mathrm{~g} / \mathrm{cm} 3$ e $10 \mathrm{~mL}$ de iodixanol $1,080 \mathrm{~g} / \mathrm{cm} 3$ foram adicionados simultaneamente através de bomba peristáltica, formando um gradiente contínuo. Para finalizar, foram adicionados $5 \mathrm{~mL}$ de iodixanol a $1,030 \mathrm{~g} / \mathrm{cm} 3$. O gradiente foi então centrifugado a $400 \mathrm{~g}$ por 20 minutos em temperatura ambiente e as IP foram coletadas com os primeiros $10 \mathrm{~mL}$ de gradiente. As IP foram lavadas em meio RPMI por três vezes, para retirada de resíduos de iodixanol e o pellet de IP purificadas foi re-suspendido em RPMI para contagem das IP após coloração com ditizona e posterior avaliação funcional.

Teste de estímulo com glicose para análise funcional das IP

A análise funcional consistiu em estimular IP em cultura com concentrações de glicose baixa $(2,75 \mathrm{mM})$ e alta $(16,5 \mathrm{mM})$ e verificar a concentração de insulina presente no sobrenadante de IP. Foram utilizadas 30 IP de aproximadamente $150 \mu \mathrm{m}$ de diâmetro, purificadas através de gradiente contínuo de iodixanol, divididas em três grupos. Cada grupo de dez IP foi colocado em placa de cultura com área de $2 \mathrm{~cm} 2$ contendo $2 \mathrm{~mL}$ de solução de Krebs (25 mM Hepes, $114 \mathrm{mM} \mathrm{NaCl}, 23 \mathrm{mM}$ NaHCO3, 5 mM KCl, 2 mM $\mathrm{CaCl} 2$ 2H2O, 0,9 mM MgCl2, 0,1\% BSA, pH 7,2) com 2,75 mM de glicose. As IP foram mantidas em incubadora a CO2 5\% durante 45 minutos e, em seguida, o sobrenadante foi coletado e substituído por $2 \mathrm{~mL}$ de solução de Krebs contendo $16,5 \mathrm{mM}$ de glicose. As IP foram novamente incubadas sob $5 \%$ de $\mathrm{CO} 2$ por 45 minutos e o sobrenadante foi coletado e substituído por $2 \mathrm{~mL}$ de solução de Krebs contendo 2,75 $\mathrm{mM}$ de glicose. As IP permaneceram por mais 45 minutos em incubadora e o sobrenadante foi coletado. A insulina presente no sobrenadante foi dosada por radioimunoensaio (RIA), utilizando-se kit específico para insulina de rato (Linco Research, Missouri, EUA).

\section{Construção do vetor de expressão para IDO Extração de RNA}

Para obtenção do cDNA da IDO, o RNA total foi extraído de placentas de ratas Lewis com 5, 10 e 15 dias de gestação, através do reagente Trizol (Invitrogen, Califórnia, EUA), seguindo-se o protocolo sugerido pelo fabricante.

\section{Reação de transcriptase-reversa}

A reação de transcrição reversa foi realizada utilizando-se o kit SuperScriptTM III Reverse Transcriptase (Invitrogen, Califórnia, EUA). Resumidamente, cinco microgramas de RNA total contidos em $11 \mu \mathrm{L}$ de água livre de RNase foram misturados a $1 \mu \mathrm{L}$ de dNTPs $(10 \mathrm{mM})$ e a $1 \mu \mathrm{L}$ de oligo $(\mathrm{dT})(50 \mu \mathrm{M})$. A mistura foi 
aquecida a $65^{\circ} \mathrm{C}$ por 5 minutos e resfriada em gelo. Em seguida, foram adicionados $4 \mu \mathrm{L}$ de $5 \mathrm{X}$ first-strand buffer, $1 \mu \mathrm{L}$ de DTT $(0,1$ M), $1 \mu \mathrm{L}$ de inibidor de RNase e $1 \mu \mathrm{L}$ de SuperScript III. A mistura foi aquecida a $50^{\circ} \mathrm{C}$ por 60 minutos e a $70^{\circ} \mathrm{C}$ por 15 minutos. Após a reação, as amostras permaneceram a $-20^{\circ} \mathrm{C}$.

\section{Reação de PCR para IDO}

A reação em cadeia da polimerase foi realizada utilizandose a enzima Platinum ${ }^{\circledR}$ Taq DNA polymerase High Fidelity (Invitrogen, Califórnia, EUA). Os primers foram desenhados para amplificar $100 \%$ do cDNA da IDO e cada primer continha uma seqüência extra formando um sítio específico para uma enzima de restrição para posterior subclonagem. Primer forward (5'-GCTAGCATGCCTCACAGTCAAATATCTCC-3'), com sítio para a enzima Nhe I, e primer reverse (5'GTTTAAACCTAAGGCCAACTCAGAAGGG-3'), com sítio para a enzima Pme I. A reação de PCR foi realizada a 35 ciclos de $94^{\circ} \mathrm{C}$ por 30 segundos, $62^{\circ} \mathrm{C}$ por 30 segundos e $72^{\circ} \mathrm{C}$ por 1 minuto. $\mathrm{O}$ produto do PCR corresponde ao cDNA da IDO, com $1224 \mathrm{pb}$.

\section{Subclonagem do cDNA específico para a IDO}

O produto do PCR de $1224 \mathrm{pb}$ foi subclonado utilizando-se o vetor pGEM-T (pGEM-T Easy Vector Systems, Promega, Madison, EUA) e a bactéria super competente One Shot ${ }^{\circledR}$ Top 10F' (Invitrogen, Califórnia, EUA). Resumidamente, dois microlitros de produto de PCR foram acrescidos de $5 \mu \mathrm{L}$ de $2 x$ rapid ligation buffer, $1 \mu$ de vetor pGEM-T, $1 \mu \mathrm{L}$ de DNA ligase e $1 \mu \mathrm{L}$ de água. Após uma hora de incubação em temperatura ambiente, $2 \mu \mathrm{L}$ da reação de ligação foram adicionados a $50 \mu \mathrm{L}$ de bactérias super competentes (One Shot ${ }^{\circledR}$ Top 10F', Invitrogen, Califórnia, EUA). As bactérias foram incubadas a $42^{\circ} \mathrm{C}$ por 50 segundos e levadas ao gelo. Foram acrescentados $950 \mu \mathrm{L}$ de meio SOC (Invitrogen, Califórnia, EUA) e as células foram incubadas a $37^{\circ} \mathrm{C}$ por duas horas sob agitação constante (150 rpm) (Amerex, Califórnia, EUA). Após incubação, $100 \mu \mathrm{L}$ de bactérias foram incubados em placas de LB Agar, contendo ampicilina $(100 \mu \mathrm{g} / \mathrm{mL}$, Strides Arcolab, Bangalore, Índia), IPTG $(1,5 \mathrm{mM})$ (Invitrogen, Califórnia, EUA) e X-Gal $(80 \mu \mathrm{g} / \mathrm{mL})$ (Invitrogen, Califórnia, EUA). As placas permaneceram a $37^{\circ} \mathrm{C}$ durante 24 horas e dez colônias brancas, resistentes a ampicilina foram colhidas e incubadas individualmente com $2 \mathrm{~mL}$ de meio $\mathrm{LB}$ (Invitrogen, Califórnia, EUA) durante 24 horas.

\section{Ligação do cDNA para IDO no vetor de expressão}

Após a subclonagem, o vetor pGEM-T foi digerido com as enzimas Pme I e Nhe I e o inserto de 1224 pb (cDNA da IDO) foi ligado ao vetor de expressão pcDNA 3.1 (Invitrogen, Califórnia, EUA). Resumidamente, após digestão, as amostras de DNA bacteriano foram submetidas à eletroforese em gel de agarose $0,8 \%$ e a banda referente ao cDNA da IDO foi eluída de gel através do kit Wizard SV Gel Clean-up (Promega, Madison, EUA). Em seguida, foi realizada reação de ligação do cDNA da IDO com o vetor de expressão pcDNA 3.1, através da ação da enzima T4 ligase (Invitrogen, Califórnia, EUA), conforme protocolo do kit.

\section{Sequenciamento do cDNA para a IDO}

A sequência do inserto IDO foi confirmada através de sequenciamento do inserto contido no vetor pcDNA $3.1(+)$. Um microlitro de vetor-IDO $(0,5 \mu \mathrm{g})$ foi acrescido de $6 \mu \mathrm{L}$ de $5 \mathrm{X}$ sequencing buffer (Applied Biosystems, Califórnia, EUA), $2 \mu \mathrm{L}$ de primer $\mathrm{T} 7$ (Invitrogen, Califórnia, EUA), $2 \mu \mathrm{L}$ de BigDye ${ }^{\circledR}$ Terminator (Applied Biosystems, Califórnia, EUA) e água para $20 \mu \mathrm{L}$. A reação foi submetida a 35 ciclos de 10 segundos a $96^{\circ} \mathrm{C}, 10$ segundos a $50^{\circ} \mathrm{C}$ e 2 minutos a $60^{\circ} \mathrm{C}$, através de termociclador (PTC-100, MJ Research, Watertown, EUA). Em seguida, foram adicionados $80 \mu \mathrm{L}$ de isopropanol (Sigma, St. Louis, EUA) e, após incubação de 25 minutos em temperatura ambiente, a mistura foi centrifugada a 13000 g por 30 minutos. O sobrenadante foi desprezado e o pellet re-suspendido em $200 \mu \mathrm{L}$ de etanol $70 \%$ e centrifugado a $13.000 \mathrm{~g}$ por 20 minutos. O sobrenadante foi desprezado e o pellet permaneceu a $37^{\circ} \mathrm{C}$ por 15 minutos para posterior sequenciamento. No sequenciamento, o pellet foi re-suspendido em tampão de corrida (Applied Biosystems, Califórnia, EUA) e injetado no seqüenciador (ABI Prism 377, Applied Biosystems, Califórnia, EUA).

\section{Transfecção das IP com o cDNA da IDO}

A transfecção do cDNA foi realizada utilizando-se técnica não-viral através da lipofectamina. Para determinar a melhor concentração do vetor-IDO para transfectar IP, grupos de 10 IP foram incubados em wells de uma placa de 96 contendo $100 \mu \mathrm{L}$ de meio RPMI (Invitrogen, Califórnia, EUA). Doze wells possuíam Lipofectamina 2000 (Invitrogen, Califórnia, EUA) $(4 \mu \mathrm{L} / \mathrm{mL}$ de meio) sem vetorIDO, 12 wells possuíam Lipofectamina 2000 mais vetor-IDO na concentração de $0,5 \mathrm{ng} / \mu \mathrm{L}, 12$ wells possuíam Lipofectamina 2000 mais vetor-IDO na concentração de $1 \mathrm{ng} / \mu \mathrm{L}$ e 12 wells possuíam Lipofectamina 2000 mais vetor-IDO na concentração de $10 \mathrm{ng} / \mu \mathrm{L}$. As IP permaneceram incubadas por 1 hora, 15 horas e 24 horas. Ao término destes períodos, três wells de cada grupo foram utilizados para extração de RNA e RT-PCR.

\section{RT-PCR para controle da eficiência da transfecção}

A expressão da IDO foi analisada por RT-PCR para avaliar a transfecção das IP. RNA total foi extraído das IP através de reagente de Trizol (Invitrogen, Califórnia, EUA) e a reação de RT-PCR foi realizada conforme descrito anteriormente. Além disso, PCR foi realizada para o gene housekeeping beta2microglobulina, utilizando-se primers específicos (forward 5'-CTCCCCAAATTCAAGTGTACTTCTG-3' e reverse 5'GAGTGACGTGTTTAACTCTGCAAGC-3'). A reação de PCR foi realizada a 35 ciclos de $94^{\circ} \mathrm{C}$ por 30 segundos, $62^{\circ} \mathrm{C}$ por 30 segundos e $72^{\circ} \mathrm{C}$ por um minuto. O produto do PCR corresponde ao cDNA da IDO, com $1224 \mathrm{pb}$.

\section{Imuno-histoquímica para controle da eficiência da transfecção}

A expressão da IDO pelas IP transfectadas em nível protéico também foi analisada. Foi realizada imuno-histoquímica para IDO em placenta de rata com 10 dias de gestação (controle) e em IP transfectadas ou não com vetor-IDO, na concentração de 10ng/ $\mu \mathrm{L}$ por 24 horas. O tecido placentário e as IP foram submetidos a bloqueios com soluções de avidina, biotina e com soro de cavalo para evitar ligações inespecíficas. Para identificação da IDO foi utilizado o anticorpo de carneiro anti-IDO de rato (1:100) (Zymed, São Francisco, EUA). Como anticorpo secundário, foi utilizado o 
anti-carneiro biotinilado (Vector, Burlingame, EUA), seguido do complexo estreptavidina-fosfatase alcalina (Dako, Carpinteria, EUA). Para a revelação, foram utilizados o substrato para a enzima fosfatase alcalina e o corante fast-red (Sigma Chemical CO, St. Louis, MO, EUA).

\section{Quantificação de triptofano por HPLC}

Para avaliar a funcionalidade da IDO produzida pelas IP transfectadas, o aminoácido triptofano foi quantificado pelo método de HPLC (High-performance liquid chromatography) no sobrenadante, após cultura das IP. As IP (2.500 IP) foram mantidas em incubadora de $\mathrm{CO} 2$ por 24 horas com RMPI $(50 \mathrm{~mL})(2 \%$ soro fetal bovino) contendo Lipofectamina ou Lipofectamina + vetorIDO (10ng/mL). Após 24 horas, o meio de cultura foi trocado e as IP permaneceram em incubadora de $\mathrm{CO} 2$ por 96 horas em RPMI contendo $10 \%$ de soro fetal bovino e antibióticos (penicilina $100 \mu \mathrm{g} / \mathrm{mL}$ e estreptomicina $100 \mu \mathrm{g} / \mathrm{mL}$ ). Para quantificação de triptofano, uma amostra de $1 \mathrm{~mL}$ do meio de cultura foi coletada após 48 horas e outra amostra foi coletada após 96 horas. O RPMI sem IP foi usado como controle. As amostras foram preparadas e injetadas automaticamente no sistema Agilent 1100 do HPLC (Agilent Technologies, Califórnia, EUA). A amostra foi eluída isocraticamente em tampão de acetato de sódio $(10 \mathrm{mmol} / \mathrm{L}) /$ acetonitrila, 96/4, com fluxo constante por 30 minutos, através de uma pré-coluna de 12,5 X 4,6mm $(5 \mu \mathrm{m})$ (Agilent Eclipse, 820950926, Agilent Technologies, Califórnia, EUA) e através de uma coluna analítica de 4,6 X 250mm $(5 \mu \mathrm{m})$ (Agilent Hypesil ODS, 7992618-585, Agilent Technologies, Califórnia, EUA). Os picos foram detectados em $280 \mathrm{~nm}$ de absorbância ultravioleta, e foram integrados por meio do software Chemstation Agilent (G2170AA, Agilent Technologies, Califórnia, EUA) e foi construída uma curva padrão com soluções de triptofano (Sigma, Sto. Louis, EUA) nas concentrações de $1,5,10$ e $20 \mathrm{mg} / \mathrm{L}$.

\section{Análise da mortalidade das IP pós-transfecção}

Para avaliar o efeito da IDO sobre a mortalidade das IP foi utilizada coloração por azul de Tripan, que cora células mortas em azul. As IP foram isoladas por gradiente contínuo de iodixanol e incubadas em placas de cultura de 24 wells ( $50 \mathrm{IP} / \mathrm{mL} /$ well) sob quatro diferentes condições: apenas com meio RPMI; com meio RPMI contendo $4 \mu \mathrm{L} / \mathrm{mL}$ de Lipofectamina 2000; com meio RPMI contendo lipofectamina 2000 + vetor-IDO; e com meio RPMI contendo lipofectamina $2000+$ vetor-CAT (controle). As IP permaneceram incubadas por quatro diferentes períodos em incubadora de $\mathrm{CO} 2$ : 1, 3, 5 e 10 dias, sendo feitas triplicatas para cada condição. Após o período de incubação, as IP foram coradas com azul de Tripan e 10 IP de cada well foram analisadas. A porcentagem de células mortas por IP foi calculada com o programa Adobe Photoshop CS, onde foi possível selecionar as células azuis e calcular a quantidade de pixels das células coradas e não-coradas.

\section{Transplante experimental de IP}

O transplante experimental foi realizado em ratos Lewis machos tornados diabéticos através de uma única injeção de estreptozotocina pela veia caudal na concentração de $55 \mathrm{mg}$ / $\mathrm{Kg}$. A glicemia dos animais foi verificada através de fotometria (Accu-Chek Advanage, Roche Laboratories, Alemanha), dois dias após a injeção de estreptozotocina e os animais que apresentavam glicemia $>300 \mathrm{mg} / \mathrm{dL}$ foram considerados diabéticos. Cinco dias após a injeção de estreptozotocina, os animais com comprovada hiperglicemia foram submetidos a transplante. Para tanto, os animais foram anestesiados com ketamina/xilazina e receberam 2.500 IP sob a cápsula renal. Resumidamente, as IP isoladas e em cultura foram coletadas em capilar de vidro com auxílio de uma micro-seringa Hamilton (Nevada, EUA). O capilar foi centrifugado a $150 \mathrm{~g}$ por um minuto e o pellet de IP foi formado na ponta do capilar de vidro. Os ratos receptores foram anestesiados através de injeção intraperitoneal de cetamina $(35,6 \mathrm{mg} / \mathrm{Kg})$ (Ketamin-S, Cristália, Brasil) e xilazina (5,7 mg/Kg) (Ronpun, Bayer, Alemanha) e submetidos a lombotomia esquerda. O rim esquerdo foi acessado e um corte de $5 \mathrm{~mm}$ foi feito na cápsula renal. $\mathrm{O}$ capilar de vidro contendo o pellet de IP foi então colocado sob a cápsula renal e as IP foram injetadas com auxílio de um micro-injetor, construído especificamente para essa finalidade.

O micro-injetor consistiu de uma seringa de vidro de $1 \mathrm{~mL}$, acoplada a um micrômetro com escala de 0,001mm (Digimess, São Paulo, Brasil). Após infusão das IP, a cápsula renal foi cauterizada e a incisão da lombotomia do animal foi suturada com fio de seda 5,0 (Ethicon, São Paulo, Brasil). A glicemia e o peso foram verificados 24 horas pós-transplante e a reversão do diabetes foi considerada quando os animais apresentaram normoglicemia.

\section{Grupos experimentais}

Transplantes isogênicos e alogênicos foram realizados no presente estudo. No transplante isogênico foram utilizados ratos Lewis como doadores e receptores. No transplante alogênico foram utilizados ratos Sprague-Dawley como doadores e ratos Lewis como receptores.

Os animais receberam 2500 IP sob a cápsula renal e foram divididos em três diferentes grupos: ISO Tx (isogênico) $(n=6)$, ratos Lewis transplantados com IP de ratos Lewis; ALO Tx (alogênico) $(\mathrm{n}=15)$, ratos Lewis transplantados com IP de ratos Srague-Dawley; e ALO+IDO Tx $(n=11)$, ratos Lewis transplantados com IP de ratos Sprague-Dawley transfectadas com vetor-IDO. Nove ratos Lewis diabéticos não-transplantados foram utilizados como controle.

Os animais foram acompanhados por 45 dias, verificando-se o peso, a glicemia e os níveis de insulina sérica. Três animais de cada um dos grupos ALO Tx e ALO+IDO Tx foram sacrificados 10 dias pós-Tx, para análise da expressão de insulina e IDO através de imuno-histoquímica.

\section{Rádioimunoensaio para dosagem de insulina}

Para realização do RIA foram utilizados kits para dosagem de insulina de rato (Linco Research, Missouri, EUA) e leitor para radiação gama (Gamma 5500B, Beckman, EUA). A curva padrão foi feita seguindo-se as orientações sugeridas pelo Kit. Foram utilizadas amostras de sangue $(0,5 \mathrm{~mL})$ colhidas antes da indução do diabetes, antes do transplante, um dia pós-transplante e 45 dias pós-transplante.

\section{Análise de imuno-histoquímica para Insulina e IDO}

Imuno-histoquímica foi utilizada para comprovar a presença de insulina e IDO no enxerto dos animais dos grupos ALO Tx e 
ALO+IDO Tx sacrificados com 10 dias. O tecido renal contendo as IP foi fixado em lâminas de vidro e foram realizados bloqueios com soluções de avidina e biotina e com soro de cavalo. Para identificação de insulina foi utilizado o anticorpo de camundongo anti-insulina de rato (1:100) (Santa Cruz, Califórnia, EUA) e para a identificação de IDO foi utilizado anticorpo de carneiro anti-IDO de rato (1:100) (Zymed, São Francisco, EUA). Como anticorpos secundários, foram utilizados o anticamundongo biotinilado absorvido em rato (Vector, Burlingame, EUA) e o anti-carneiro biotinilado (Vector, Burlingame, EUA), seguidos do complexo estreptavidina-fosfatase alcalina (Dako, Carpinteria, EUA). Para a revelação, foram utilizados o substrato para a enzima fosfatase alcalina e o corante fast-red (Sigma Chemical CO, St. Louis, MO, EUA).

A porcentagem de tecido positivo tanto para insulina como para IDO foi calculada através do programa Image Pro-Plus 6.0 (Media Cybernetics, MD, EUA).

\section{Análise da sobrevida das IP}

A sobrevida das IP pós-transplante foi determinada pelo tempo em que os animais permaneceram com glicemia $<300 \mathrm{mg} / \mathrm{dL}$. Mais especificamente, a sobrevida foi determinada pelo tempo entre o transplante e o dia em que os animais retornaram com glicemia $>300 \mathrm{mg} / \mathrm{dL}$, a qual deveria permanecer alta por no mínimo 3 dias consecutivos.

\section{Análise estatística}

Os resultados são apresentados como média \pm erro padrão. Para comparação entre os diferentes grupos foram utilizados testes ANOVA One-way com pós-teste de Newman-Keuls ou t-Student não pareado. Para análise da sobrevida foi utilizado o método Kaplan-Meier seguido do teste Logrank para comparação entre as curvas. A significância estatística foi considerada a partir de $\mathrm{p}<0,05$.

\section{RESULTADOS}

\section{Isolamento de IP}

O gradiente contínuo de iodixanol foi eficiente para recuperar IP com alto grau de pureza (Figura 1A). A análise funcional, que consistiu em quantificar por radioimunoensaio a insulina no sobrenadante de IP após incubação com baixa $(2,75 \mathrm{mM})$ e alta $(16,5 \mathrm{mM})$ concentrações de glicose, demonstrou que IP purificadas por gradiente contínuo de iodixanol secretam insulina adequadamente, frente às diferentes concentrações de glicose (Figura 1B). Durante a primeira incubação com baixa concentração de glicose $(2,75 \mathrm{mM})$ houve secreção basal de insulina $(2,9 \pm 0,6 \mathrm{ng} / 10 \mathrm{IP} / 45$ minutos). Como estímulo utilizando-se alta concentração de glicose $(16,5 \mathrm{mM})$, houve aumento significativo na secreção de insulina pelas IP $(7,7 \pm 1,6$ $\mathrm{ng} / 10 \mathrm{IP} / 45$ minutos; $\mathrm{p}<0,05)$.

Quando o estímulo foi retirado e as IP foram incubadas pela segunda vez com baixa concentração de glicose $(2,75 \mathrm{mM})$, a secreção de insulina voltou ao nível basal $(2,6 \pm 0,2 \mathrm{ng} / 10 \mathrm{IP} / 45$ minutos), demonstrando função adequada da produção de insulina pelas IP isoladas.
Figura 1. (A) IP coradas com ditizona. Isolamento realizado através de gradiente contínuo de iodixanol, fornecendo IP integras e livres de tecido acinar. (B) Secreção de insulina frente às diferentes concentrações de glicose. Dosagem de insulina por radioimunoensaio no sobrenadante de IP isoladas através gradiente contínuo de iodixanol
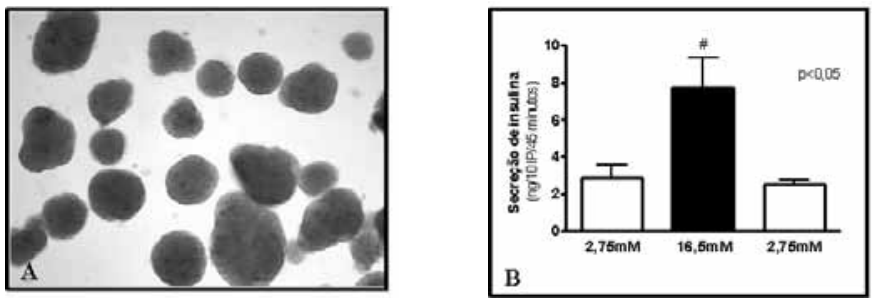

\section{Construção do vetor de expressão para IDO}

RT-PCR para IDO de placenta de ratas Lewis demonstrou que em todos os períodos de gestação $(5,10$ e 15 dias) houve expressão de IDO (Figura 2A). Esse cDNA adquirido pela técnica de RT-PCR foi ligado em vetor de clonagem com sucesso, pois a digestão do vetor de clonagem com a enzima de restrição Eco RI após a reação de ligação forneceu um fragmento de 1224 pb referente ao cDNA da IDO. Além disso, o sucesso da ligação do cDNA da IDO no vetor de expressão pcDNA 3.1. foi confirmado pela digestão do vetor com as enzimas de restrição Pme I, Nhe I e Bam HI. A digestão com Pme I e Nhe I forneceu concomitantemente um fragmento de $1224 \mathrm{pb}$, confirmando a presença de cDNA da IDO no vetor (Figura 2B). Reforçando o resultado, a digestão do vetor com Bam HI forneceu fragmento de $547 \mathrm{pb}$, referente a uma sequência do cDNA da IDO (Figura 2B). A sequência do cDNA da IDO foi confirmada através de sequenciamento (dados não apresentados).

Figura 2. (A) Foto de gel de agarose 1\%. Linha 1: ladder 100/100 pb; linhas 2, 3 e 4, produto de PCR para IDO em 5, 10 e 15 dias de gestação, respectivamente. (B) Imagem do gel de agarose 1\%: linha 1, ladder 100/100 pb; linha 2, vetor não-digerido; linha 3, vetor digerido com Pme I e Nhe l; e linha 4, vetor digerido com Bam HI
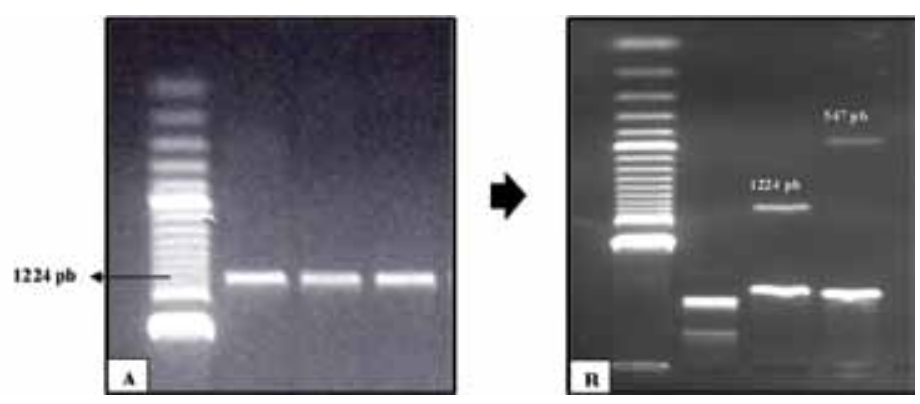

\section{Transfecção das IP}

Análise da eficiência da transfecção através da detecção de RNAm para IDO

IP incubadas durante uma hora com lipofectamina + vetor IDO nas concentrações $0,5,1,0$ e $10 \mathrm{ng} / \mu \mathrm{l}$ não apresentaram expressão para IDO (Figura 3). No entanto, após 15 horas de incubação nas mesmas condições, as IP passaram a expressar IDO de maneira proporcional à quantidade de vetor IDO (Figura 3). A expressão máxima deu-se após 24 horas de incubação nas concentrações 
de 1 e $10 \mathrm{ng} / \mu \mathrm{l}$ (Figura 3).

Com esses resultados, a condição utilizada para induzir a expressão da IDO nas IP antes do transplante foi a concentração de $10 \mathrm{ng} / \mu \mathrm{L}$ durante 24 horas. A eficiência dessa condição para induzir a expressão de IDO foi confirmada também por imuno-histoquímica. Como esperado, foi possível identificar a presença de IDO em placenta e também em IP transfectadas com vetor-IDO, confirmando a eficiência do vetor-IDO em induzir a produção da enzima IDO.

Figura 3. (A) Foto de gel de agarose $1 \%$ demonstrando os produtos de RT-PCR para 2-microglobulina e IDO. RT-PCR de IP transfectadas com vetor IDO em diferentes concentrações e em diferentes períodos de incubação. (B) Gráfico demonstrando a relação entre a expressão de IDO/ 2-microglobulina em IP transfectadas com vetor IDO em diferentes concentrações e em diferentes períodos de incubação

(A)

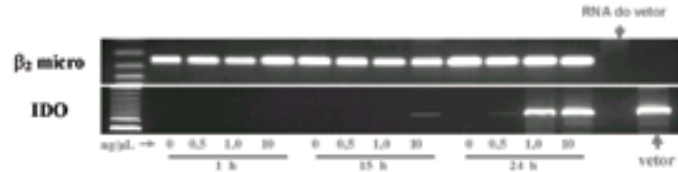

(B)

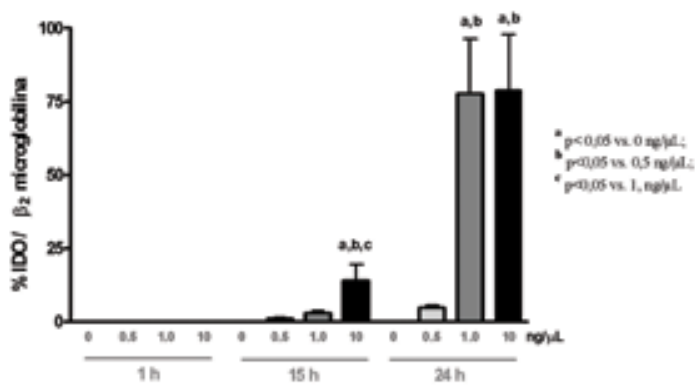

\section{Análise da eficiência da transfecção através da avaliação funcional da IDO}

Para analisar se a produção de IDO a partir de IP transfectadas com o cDNA da IDO encontrava-se funcionalmente ativa, foi analisada a degradação de triptofano em sobrenadante de cultura.

IP transfectadas com vetor IDO degradaram significativamente mais triptofano após 48 horas comparadas com IP sem transfecção $(2,73+0,03 \mathrm{ng} / \mu \mathrm{L}$ no grupo LIPO+IDO vs. $2,95+0,04 \mathrm{ng} / \mu \mathrm{L}$ no grupo LIPO; $\mathrm{p}<0,05)$. Após 96 horas, o efeito foi acentuado, ou seja, houve maior degradação de triptofano pelas IP, e as transfectadas com vetor IDO degradaram significativamente mais triptofano comparadas com as IP não-transfectadas $(1,04+0,30 \mathrm{ng} / \mu \mathrm{L}$ no grupo LIPO+IDO vs. $2,22+0,32 \mathrm{ng} / \mu \mathrm{L}$ no grupo LIPO; $\mathrm{p}<0,05)$.

\section{Análise da mortalidade das IP pós-transfecção}

A mortalidade das IP foi analisada através de coloração com azul de Tripan, onde as células mortas apresentavam coloração azulada. IP não-transfectadas (Controle), ou seja, incubadas apenas com meio RPMI, apresentaram baixa porcentagem de células mortas após um dia de cultura e essa mortalidade aumentou após 3, 5 e 10 dias de cultura, porém, sem diferença significativa. A presença de lipofectamina, a transfecção com o vetor-IDO e a transfecção com vetor-CAT (gene controle) não influenciaram a mortalidade das IP.

\section{Efeito da expressão da IDO em transplante experimental de IP}

\section{Evolução ponderal}

Com relação aos grupos experimentais, o primeiro parâmetro analisado foi a evolução ponderal dos animais ao longo do período de acompanhamento. Animais diabéticos nãotransplantados apresentaram significativa redução da massa corporal ao longo do período de acompanhamento $(297 \pm 14$ g no pré-DM vs. $244 \pm 28$ g 45 dias pós-DM; $\mathrm{p}<0,05)$. Os animais diabéticos transplantados com IP isogênicas (ISO Tx) apresentaram redução da massa corporal até o dia do transplante ( $302 \pm 4$ g no pré-DM vs. $283 \pm 7$ g no pré-TX; $p<0,05)$, e, após o transplante, tiveram ganho significativo de massa ao longo de 45 dias $(340 \pm 7$ g vs. $283 \pm 7$ g no pré-Tx; $p<0,05)$. Os animais transplantados com IP alogênica (ALO Tx) perderam peso ao longo de 45 dias de forma semelhante aos animais diabéticos sem transplante de IP $(304 \pm 5$ g no pré-DM vs. $256 \pm 6 \mathrm{~g} 45$ dias pós-Tx; $p<0,05)$. Já os animais transplantados com IP alogênicas expressando IDO (ALO+IDO Tx) ganharam massa significativa ao longo dos 45 dias pós-transplante $(265 \pm 3 \mathrm{~g}$ no pré-Tx vs. $310 \pm 6$ g 45 dias pós-Tx).

\section{Análise de imuno-histoquímica para Insulina e IDO}

O enxerto constituído por IP não transfectadas com vetor-IDO apresentou pouca marcação para insulina 10 dias pós-transplante $(0,08 \pm 0,05 \%)$ (Figura 4A), enquanto que o enxerto de IP transfectadas com vetor-IDO apresentou aumento significativo na expressão de insulina $(2,3 \pm 0,8 \%$ vs. $0,08 \pm 0,05 \%$ no grupo ALO Tx; $<<0,001$ ) (Figura 4C). Como esperado, apenas IP transfectadas com o vetor-IDO apresentaram positividade para a IDO (Figura 4D).

Figura 4. Imuno-histoquímica para insulina e para IDO em IP (setas) 10 dias pós-transplante. Todos os enxertos apresentaram positividade para insulina $(A \in C)$. Apenas IP transfectadas com o vetor IDO (ALO+IDO $T x$ ) apresentaram positividade para IDO (D). Porcentagem de enxerto apresentando marcação para insulina através de análise por imunohistoquímica (abaixo)
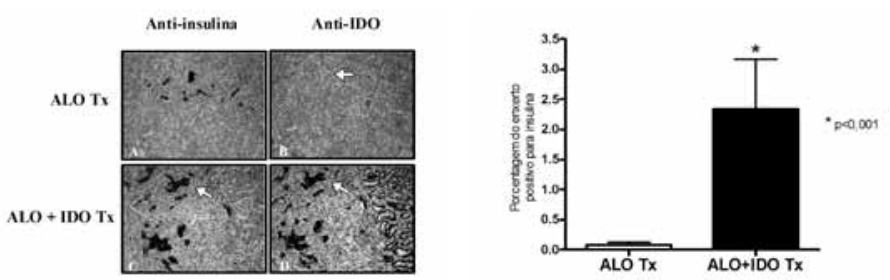

\section{Evolução da glicemia pós-transplante de IP}

Com relação à glicemia, os animais transplantados com IP isogênicas reverteram o diabetes 24 horas pós-transplante e permaneceram normoglicêmicos ao longo de 45 dias (Figura 5). 
Já os animais transplantados com IP alogênicas (Sprague Dawley $\rightarrow$ Lewis) reverteram o diabetes 24 horas pós-transplante, porém a glicemia voltou a subir gradativamente, alcançando valores $>300 \mathrm{mg} / \mathrm{dL}$ após aproximadamente 11 dias (Figura 5). Esses animais do grupo ALO Tx evoluíram com hiperglicemia importante (mantendo glicemia $>300 \mathrm{mg} / \mathrm{dL}$ ) ao longo do período de acompanhamento, sendo inclusive necessário sacrificá-los devido ao comprometimento clínico dos animais. Já os animais transplantados com IP alogênicas transfectadas com vetorIDO, além de reverterem o diabetes, 24 horas pós-transplante mostraram um interessante comportamento da glicemia, no qual mais tardiamente foi detectado um pico isolado de hiperglicemia, que, de forma surpreendente, normalizou espontaneamente nos dias subseqüentes. A glicemia foi mantida $<300 \mathrm{mg} / \mathrm{dL}$ durante o período de acompanhamento em cinco animais, um deles com níveis um pouco acima da faixa de $300 \mathrm{mg} / \mathrm{dL}$ (Gráfico 2). Cabe ressaltar que dois animais do grupo ALO+IDO Tx evoluíram de forma idêntica ao transplante alogênico e influenciaram nos resultados apresentados acima. Aqueles animais foram transplantados no último experimento do estudo, e é possível ter havido alguma variação técnica que tenha impedido a transfecção das IP com o cDNA da IDO.

Figura 5. Média de glicemia de cada grupo experimental ao longo dos 45 dias de acompanhamento

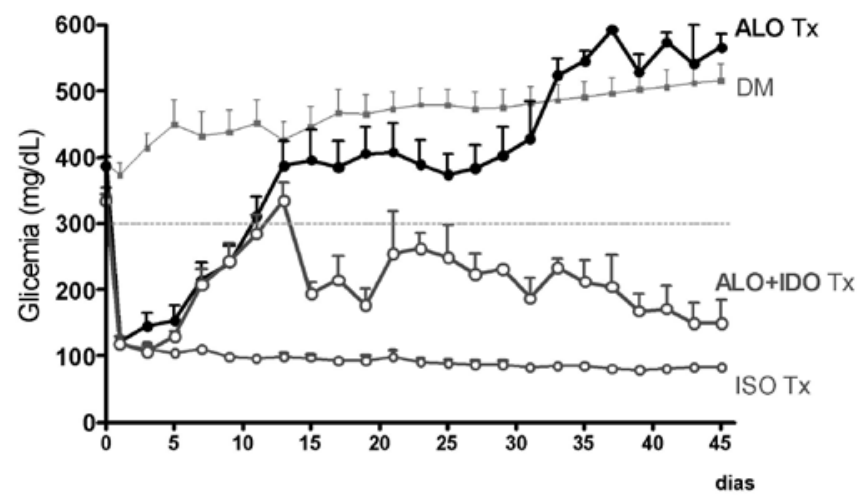

\section{Análise da insulinemia pós -transplante de IP}

A insulinemia também foi analisada nos animais deste estudo. A partir do valor normal da insulinemia para ratos (entre 0,5-2,0 $\mathrm{ng} / \mathrm{mL}$ ), pudemos observar que os animais utilizados para formar os diferentes grupos experimentais apresentaram insulinemia normal antes de iniciar o protocolo (Tabela 1). A análise estatística comparando a glicemia dos animais normais (Pré-DM) entre os diferentes grupos não foi estatisticamente diferente. Após injeção de estreptozotocina, todos os animais tornaram-se diabéticos, apresentando aproximadamente $90 \%$ de redução da insulinemia (Tabela 1). Como esperado, os animais transplantados com IP apresentaram um dia pós-transplante normalização da insulinemia (Tabela 1). Após 45 dias, os animais do grupo DM (diabéticos não-transplantados) continuaram a apresentar insulinemia significativamente reduzida (Tabela 1) $(\mathrm{p}<0,01)$.

Os animais transplantados com IP isogênicas apresentaram insulinemia normal 45 dias pós-transplante (Tabela 1). Diferentemente dos animais do grupo ISO Tx, os animais transplantados com IP alogênicas apresentaram insulinemia reduzida, semelhante aos animais do grupo DM (Tabela 1). Já os animais transplantados com IP alogênicas transfectadas com vetor-IDO apresentaram baixos níveis de insulina sérica 45 dias pós-transplante, porém, os níveis foram superiores aos encontrados nos animais do grupo ALO Tx no mesmo período $(\mathrm{p}<0,01)$.

\begin{tabular}{|l|c|c|c|c|}
\hline Grupos & $\begin{array}{c}\text { Normal } \\
\text { (antes da } \\
\text { indução do } \\
\text { DM) } \\
(\mathbf{n g} / \mathbf{m L})\end{array}$ & $\begin{array}{c}\text { Pré-Tx } \\
\mathbf{( D M} \\
\text { estabelecido) } \\
(\mathbf{n g} / \mathbf{m L})\end{array}$ & $\begin{array}{c}\text { Pós-Tx } \\
\mathbf{1} \mathbf{~ d i a} \\
\mathbf{( n g} / \mathbf{m L})\end{array}$ & $\begin{array}{c}\text { Pós-Tx } \\
\mathbf{4 5} \text { dias } \\
\mathbf{( n g} / \mathbf{m L})\end{array}$ \\
\hline $\begin{array}{l}\text { DM (sem } \\
\text { Tx })\end{array}$ & $0,91 \pm 0,16$ & $0,11 \pm 0,02 *, \mathrm{a}$ & $0,10 \pm 0,01 *, \mathrm{a}$ & $0,05 \pm 0,03 *, \mathrm{a}$ \\
\hline ISO Tx & $0,54 \pm 0,29$ & $0,05 \pm 0,04 \mathrm{a}$ & $0,54 \pm 0,09 \mathrm{~b}$ & $0,55 \pm 0,13 \mathrm{~b}$ \\
\hline ALO & $0,97 \pm 0,26$ & $0,10 \pm 0,03 \mathrm{a}$ & $1,10 \pm 0,28 \mathrm{~b}$ & $0,14 \pm 0,02 \mathrm{a}, \mathrm{c}$ \\
\hline ALO+IDO & $0,66 \pm 0,06$ & $0,11 \pm 0,04 \mathrm{a}$ & $0,64 \pm 0.05 \mathrm{~b}$ & $\begin{array}{c}0,33 \pm 0,04 \\
\mathrm{a}, \mathrm{b}, \mathrm{c}\end{array}$ \\
\hline
\end{tabular}

\section{Sobrevida pós-transplante das IP}

Finalmente, a sobrevida das IP foi determinada pelo período entre o transplante e o dia em que os animais atingiram glicemia $>300 \mathrm{mg} / \mathrm{dL}$, permanecendo com hiperglicemia por mais três dias consecutivos. Os animais submetidos a isotransplante não apresentaram rejeição às IP (Figura 6). Os animais transplantados com IP alogênica rejeitaram o enxerto em poucos dias $(11+1$ dias), com falência total do enxerto. Cinco dos oito animais transplantados com IP alogênica transfectada com vetor IDO mantiveram glicemia $<300 \mathrm{mg} / \mathrm{dL}$ durante os 45 dias. Os outros três animais apresentaram sobrevida da IP de 7, 11 e 13 dias respectivamente.

Figura 6. Sobrevida das IP em isotransplante (ISO TX), alotransplante (ALO TX) e alotransplante com IP transfectadas com vetor-IDO (ALO+IDO TX)

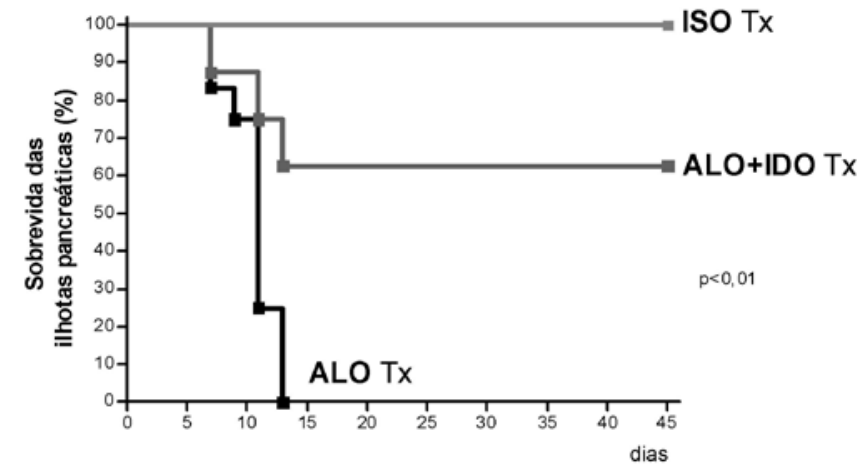

\section{DISCUSSÃO}

O presente estudo teve como objetivo principal analisar o efeito da indução da expressão da molécula IDO em IP alogênicas transplantadas experimentalmente. Mais especificamente, utilizar a terapia gênica para induzir a expressão da IDO com o intuito de proteger as IP transplantadas, permitindo maior sobrevida das mesmas. 
O método utilizado para purificação das IP foi o gradiente contínuo de iodixanol, que tem mostrado maior eficácia do que o gradiente contínuo de Ficoll na purificação de IP de ratos.15 Os resultados de viabilidade funcional das IP, ou seja, a capacidade de secreção de insulina frente à alta concentração de glicose demonstraram que as IP purificadas através de gradiente contínuo de iodixanol apresentaram viabilidade preservada, possibilitando seu uso em transplante. Uma etapa fundamental do estudo foi a construção do vetor-IDO para indução da expressão da enzima IDO. O primeiro passo foi a obtenção do cDNA específico para IDO, o qual foi isolado de placenta, um dos tecidos que sabidamente expressam a IDO.16 A técnica de RT-PCR demonstrou que há expressão de IDO em tecido placentário de ratas com 5, 10 e 15 dias de gestação, assim como descrito para camundongos. 3 Essa expressão se deve provavelmente à grande importância da IDO em proteger o embrião durante a gravidez. $6 \mathrm{O}$ cDNA foi inserido com sucesso no vetor de expressão pcDNA 3.1, o qual foi escolhido especialmente por conter o promotor do citomegalovírus, o que garante a expressão contínua do inserto.

Até recentemente, o principal método para transfecção de genes baseava-se no uso de vetores virais. No entanto, além das óbvias limitações de aplicação clínica e da citotoxicidade induzida por essa infecção, uma limitação importante é que esses vetores dependem de proteínas virais para a invasão celular, o que induz a uma forte resposta imunológica.16-18 Tendo em vista que o objetivo do estudo foi analisar uma alternativa para diminuir a rejeição às células transplantadas, a presença de proteínas virais nessas células poderia promover um agravamento da agressão imunológica, comprometendo os resultados do estudo. O presente estudo utilizou com sucesso a lipofectamina para introduzir o vetor-IDO nas células das IP e determinou a concentração ideal do vetor-IDO para induzir a expressão da IDO nas IP, alcançando expressão máxima. Um ponto de crucial importância é a avaliação da eficiência da transfecção do gene em questão nas IP. Além da confirmação da indução da expressão da IDO ao nível do RNA mensageiro, foram realizados experimentos de imuno-histoquímica para identificar a tradução da IDO em IP transfectadas. Os resultados confirmaram a presença da enzima em IP após a transfecção. Além disso, foi avaliada a funcionalidade da IDO produzida pelas IP transfectadas. A quantificação de triptofano por HPLC em meio de cultura revelou que houve maior depleção de triptofano no meio de cultura de IP transfectadas com o vetor-IDO. Isso comprova que a transfecção foi eficiente para induzir a expressão da IDO e a enzima possui atividade nas IP. Além disso, os resultados de imuno-histoquímica para IDO demonstraram que apenas os animais transplantados com IP transfectadas apresentaram expressão de IDO no enxerto 10 dias pós-transplante. Os resultados obtidos no presente estudo referentes à indução da expressão da IDO em IP são semelhantes aos resultados do estudo do efeito da IDO em IP em modelo de doença auto-imune.14 Estes pesquisadores utilizaram vetor de adenovírus para indução de IDO em IP de camundongos e a enzima funcionou, degradando triptofano em cultura.14 Um questionamento importante surgiu quanto a um possível efeito tóxico da IDO em IP, uma vez que a expressão da enzima não foi constatada por RT-PCR em IP normais (não-transfectadas). Os resultados demonstraram que a indução da expressão de IDO não tem efeito tóxico nas IP.

Além disso, IP transfectadas com vetor-IDO são capazes de reverter o diabetes após o transplante, semelhantemente às IP não transfectadas, ou seja, isso indica que a IDO não interfere na função das células-beta.Resultados interessantes foram obtidos quanto ao efeito "in vivo" da IDO no presente estudo utilizando o modelo experimental alogênico de transplante de IP.

Com relação à evolução ponderal, enquanto os animais diabéticos sem tratamento ou submetidos ao transplante com IP alogênicas não-transfectadas apresentaram perda significativa de massa corporal, os animais do grupo ALO+IDO Tx mantiveram massa corporal semelhante aos animais do grupo ISO Tx. Isso pode ser explicado pela melhora do distúrbio metabólico pós-transplante nos grupos ISO Tx e ALO+IDO Tx ao longo do período de acompanhamento.

Analisando os níveis de glicemia pós-transplante, os animais que receberam IP isogênicas reverteram o diabetes após o transplante e permaneceram com glicemia normal, por volta de $100 \mathrm{mg} / \mathrm{dL}$, durante todo período de acompanhamento. A manutenção da glicemia em valores normais de forma permanente se deve ao sucesso do transplante e ao fato das IP não terem sido rejeitadas. Em contraste, os 12 animais transplantados com IP alogênicas não-transfectadas com o cDNA da IDO apresentaram reversão do diabetes imediatamente após o transplante, porém, houve um aumento gradativo da glicemia, a qual atingiu níveis $>300 \mathrm{mg} / \mathrm{dL}$ em torno do $11^{\circ}$ dia pós-transplante, possivelmente decorrente do processo de rejeição aguda ao aloenxerto.20 Essa hiperglicemia manteve-se permanentemente $>300 \mathrm{mg} / \mathrm{dL}$ ao longo do período de acompanhamento, refletindo falência do enxerto de IP. Por outro lado, quando os animais do grupo ALO+IDO Tx receberam IP alogênicas transfectadas com o cDNA IDO, também reverteram o diabetes prontamente após o transplante e não evoluíram com perda do enxerto, como ocorreu no grupo ALO Tx. Logo após a reversão do diabetes pós-transplante, houve um progressivo aumento da glicemia, que se manteve, no entanto, em níveis $<300 \mathrm{mg} / \mathrm{dL}$. A monitorização da glicemia naquele grupo mostrou um interessante comportamento, no qual mais tarde foi detectado um pico isolado de hiperglicemia que, de forma surpreendente, foi normalizado espontaneamente nos dias subseqüentes, mantendo a glicemia $<300 \mathrm{mg} / \mathrm{dL}$ durante o período de acompanhamento.

A explicação para esse comportamento da glicemia póstransplante nos animais ALO+IDO Tx não está clara. No entanto, o fato dos animais diabéticos transplantados com IP alogênicas expressando IDO terem mantido níveis de glicemia em valores considerados dentro da faixa de normalidade sugere fortemente que a expressão de IDO teve participação efetiva na sobrevida das IP. Estudos adicionais estão sendo realizados, inclusive com análise histológica, na tentativa de proporcionar maiores esclarecimentos dos mecanismos envolvidos na proteção induzida pela IDO.

Com relação à insulinemia, os animais diabéticos sem tratamento mantiveram níveis extremamente baixos de insulina sérica ao término do período de acompanhamento, o que corrobora os achados de hiperglicemia neste grupo. A insulinemia dos animais transplantados com IP isogênicas manteve-se em níveis normais ao término do período de acompanhamento, acompanhando a glicemia em níveis normais. Esse efeito provavelmente é um reflexo do controle fisiológico mantido pelas IP transplantadas. Em contraste, os animais transplantados com IP alogênicas não-transfectadas apresentaram níveis extremamente baixos de insulina sérica ao término do período de acompanhamento, confirmando a falência funcional das IP. Os animais do grupo ALO+IDO Tx apresentaram níveis significativamente mais elevados do que os animais do grupo ALO Tx, refletindo a 
secreção de insulina no grupo transplantado com IP alogênicas transfectadas com IDO. A análise de imuno-histoquímica demonstrou que o enxerto de IP transfectadas apresentou uma expressão de insulina significativamente maior comparado ao enxerto com IP não-transfectadas, demonstrando que a insulina sérica mantida foi dependente do enxerto funcionante. Esses resultados justificam os achados de glicemia que se mostraram $<300 \mathrm{mg} / \mathrm{dL}$ durante o período de acompanhamento.

O objetivo mais importante do estudo foi saber se a expressão da IDO foi eficaz em promover aumento na sobrevida das IP transplantadas em situação alogênica. Considerando todos os animais do grupo ALO+IDO Tx, os resultados demonstraram que IP transfectadas com vetor-IDO apresentam sobrevida significativamente maior do que IP não-transfectadas.

Os resultados do presente estudo demonstram que a indução da expressão da IDO em IP protege as IP em modelo experimental de transplante alogênico. Os mecanismos pelos quais a IDO protege as IP não foram elucidados neste estudo, porém, trabalhos publicados anteriormente sugerem que a atividade da IDO local leva à deficiência de triptofano no micro-ambiente, inibindo a proliferação de linfócitos T.4 Além disso, os catabólitos (produtos da quinurenina) formados pela degradação do triptofano podem exercer imunossupressão local no micro-ambiente por induzir neutralização mitótica e apoptose em linfócitos T.8, 9,19

O potente efeito imunomodulador da IDO tem sido recentemente investigado em transplante de órgãos. A indução da expressão da IDO através de transfecção aumenta a sobrevida do enxerto em transplante alogênico experimental de pulmão, córnea e pele.1013 Aqueles trabalhos não apenas estão em concordância com os resultados do presente estudo, como também abrem caminho para uma nova via de compreensão dos mecanismos de rejeição e tolerância imunológica, podendo eventualmente ser utilizada como futura ferramenta terapêutica.

\section{CONCLUSÃO}

O presente estudo demonstrou que é possível isolar o cDNA da IDO de placenta e induzir a expressão da IDO em IP através de vetores não-virais. Os resultados demonstram que a indução da expressão da IDO em IP prolonga a sobrevida das IP em transplante alogênico, mantendo melhor controle metabólico. Estes resultados não apenas estão em concordância com outros estudos com IDO em transplante experimental, como também abrem caminho para uma nova via de compreensão dos mecanismos de rejeição e tolerância imunológica, podendo eventualmente ser utilizada como futura ferramenta terapêutica.

\section{ABSTRACT}

Purpose: The blockade of allograft rejection is essential to a successful pancreatic islet (PI) transplantation. An attractive alternative arises from the immunological paradox during pregnancy, when the mother does not reject the allogeneic fetus. This protection may be due to the IDO production in the placenta. Purpose: To isolate the IDO cDNA, to construct a vector expression for IDO and to analyze the effect of the IDO expression into PI in an experimental model of PI transplantation. Methods: The IDO cDNA was isolated from rat placenta and inserted in the pcDNA 3.1 vector. PI were transfected using Lipofectamine and different concentrations of the IDO-vector were analyzed. The IDO expression was confirmed by RT-PCR, immunohistochemistry and functional analysis. Lewis rats with streptozotocin-induced diabetes (glycemia $>300 \mathrm{mg} / \mathrm{dL}$ ) received islets under the kidney capsule and they were distributed among groups: SYN Tx (syngeneic), Lewis recipients transplanted with islets from Lewis rats; ALLO Tx (allogeneic), Lewis recipients of islets from Sprague-Dawley rats; and ALLO+IDO Tx, Lewis recipients of IDO-transfected islets from Sprague-Dawley rats. Results: The SYN Tx rats presented permanent normoglycemia, while the ALLO Tx rats returned to hyperglycemia ( $>300 \mathrm{mg} / \mathrm{dl})$ few days after transplantation (11+1 days). In contrast, ALLO+IDO Tx rats presented glycemia $<300 \mathrm{mg} / \mathrm{dL}$ during a longer-term follow-up. At day 45 , the SYN Tx group presented normal levels of serum insulin $(0.55+0.13 \mathrm{ng} / \mathrm{mL})$, while the ALLO Tx group presented a significantly reduction $(0.14+0.02 \mathrm{ng} / \mathrm{mL} ; \mathrm{p}<0.05)$. The ALLO+IDO Tx group presented significantly higher levels than the ALLO Tx group $(0.33+0.04 \mathrm{ng} / \mathrm{mL} ; \mathrm{p}<0.05)$. Conclusion: The induction of IDO expression protects the islets, increasing islets survival and improving the metabolic control.

Keywords: Pancreatic islets; Graft Rejection; Gene Therapy; Diabetes Mellitus

\section{REFERÊNCIAS}

1 Fiorina P, Gremizzi C, Maffi P, Caldara R, Tavano D, Monti L, et al. Islet transplantation is associated with an improvement of cardiovascular function in type 1 diabetic kidney transplant patients. Diabetes Care. 2005;28(6):1358-65.

2 Fiorina P, Folli F, Bertuzzi F, Maffi P, Finzi G, Venturini M, et al. Long-term beneficial effect of islet transplantation on diabetic macro-/microangiopathy in type 1 diabetic kidney-transplanted patients. Diabetes Care. 2003;26(4):1129-36.

3 Venturini M, Fiorina P, Maffi P, Losio C, Vergani A, Secchi A, et al. Early increase of retinal arterial and venous blood flow velocities at color Doppler imaging in brittle type 1 diabetes after islet transplant alone. Transplantation. 2006;81(9):1274-7.

4 Shapiro AM, Lakey JRT, Ryan EA, Korbutt GS, Toth E, Warnock GL, et al.
Islet transplantation in seven patients with type 1 diabetes mellitus using a glucocorticoidfree immunosuppressive regimen. N Engl J Med. 2000;343:230-8.

5 Shapiro AM, Ricordi C, Hering BJ, Auchincloss H, Lindblad R, Robertson RP, et al. International trial of the Edmonton protocol for islet transplantation. N Engl J Med. 2006;355:1318-30.

6 Munn DH, Zhou M, Attwood JT, Bondarev I, Conway SJ, Marshall B, et al. Prevention of Allogeneic Fetal Rejection by Tryptophan Catabolism. Science. 1998;21:1191-3.

7 Munn DH, Shafizadeh E, Attwood JT, Bondarev I, Pashine A, Mellor AL. Inhibition of $\mathrm{T}$ cell proliferation by macrophage tryptophan catabolism. J Exp Med. 1999;189:1363-72. 
8 Terness P, Bauer TM, Rose L, Dufter C, Watzlik A, Simon H, et al. Inhibition of allogeneic T cell proliferationby indoleamine2,3-dioxygenase-expressing dendritic cells:mediation of suppression by tryptophan metabolites. J Exp Med. 2002;196:447-57.

9 Fallarino F, Grohmann U, Vacca C, Bianchi R, Orabona C, Spreca A, et al. T cell apoptosis by tryptophan catabolism. Cell Death Differ. 2002;9:1069-77.

10 Li Y, Tredget EE, Ghaffari A, Lin X, Kilani RT, Ghahary A. Local expression of indoleamine 2,3-dioxygenase protects engraftment of xenogeneic skin substitute. $\mathrm{J}$ Invest Dermatol. 2006;126:128-36.

11 Swanson KA, Zheng Y, Heidler KM, Mizobuchi T, Wilkes DS. CDllc+ cells modulate pulmonary immune responses by production of indoleamine 2,3-dioxygenase. Am J Respir Cell Mol Biol. 2004;30:311-8.

12 Liu H, Liu L, Fletcher BS, Visner GA. Novel action of indoleamine 2,3-dioxygenase attenuating acute lung allograft injury. Am J Respir Crit Care Med. 2006;173:566-72.

13 Beutelspacher SC, Pillai R, Watson MP, Tan PH, Tsang J, McClure MO, et al. Function of indoleamine 2,3-dioxygenase in corneal allograft rejection and prolongation of allograft survival by over-expression. Eur J Immunol. 2006;36:690-700.

14 Alexander AM, Crawford M, Bertera S, Rudert W, Takikawa O, Robbins PD, et al
Indoleamine 2,3-dioxygenase expression in transplanted NOD islets prolongs graft survival after adoptive transfer of diabetogenic splenocytes. Diabetes. 2002;51:356-65.

15 Delle H, Saito MH, Yoshimoto PM, Noronha IL. The use of iodixanol for the purification of rat pancreatic islets. Transplant Proc. 2007;39:467-9.

16 Kamimura S, Eguchi K, Yonezawa M, Sekiba K. Localization and developmental change of indoleamine 2,3-dioxygenase activity in the human placenta. Acta Med Okayama. 1991;45:135-9.

17 Csete ME, Benhamou PY, Drazan KE, Wu L, McIntee DF, Afra R, et al. Efficient gene transfer to pancreatic islets mediated by adenoviral vectors. Transplantation. 1995;59:263-8.

18 Yang Y, Su Q, Wilson JM. Role of viral antigens in destructive cellular immune responses to adenovirus vector-transduced cells in mouse lungs. J Virol. 1996;70:7209-12.

19 Bauer TM, Jiga LP, Chuang JJ, Randazzo M, Opelz G, Terness P. Studying the immunosuppressive role of indoleamine 2,3-dioxygenase: tryptophan metabolites suppress rat allogeneic T-cell responses in vitro and in vivo. Transpl Int. 2005;18:95-100. 